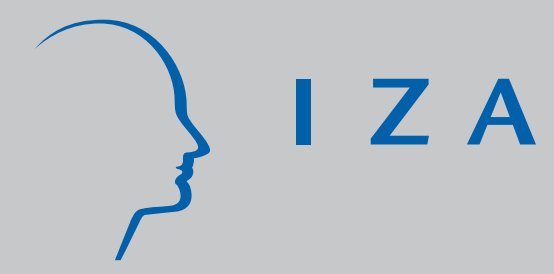

IZA DP No. 899

Unemployment in the European Union: Institutions, Prices, and Growth

Marika Karanassou

Hector Sala

Dennis J. Snower

October 2003 


\title{
Unemployment in the European Union: Institutions, Prices, and Growth
}

\author{
Marika Karanassou \\ Queen Mary, University of London \\ and IZA Bonn \\ Hector Sala \\ Universitat Autònoma de Barcelona \\ and IZA Bonn \\ Dennis J. Snower \\ Birkbeck College, University of London, \\ CEPR and IZA Bonn
}

\author{
Discussion Paper No. 899 \\ October 2003
}

\author{
IZA \\ P.O. Box 7240 \\ D-53072 Bonn \\ Germany \\ Tel.: +49-228-3894-0 \\ Fax: +49-228-3894-210 \\ Email: iza@iza.org
}

\begin{abstract}
This Discussion Paper is issued within the framework of IZA's research area Internationalization of Labor Markets. Any opinions expressed here are those of the author(s) and not those of the institute. Research disseminated by IZA may include views on policy, but the institute itself takes no institutional policy positions.
\end{abstract}

The Institute for the Study of Labor (IZA) in Bonn is a local and virtual international research center and a place of communication between science, politics and business. IZA is an independent, nonprofit limited liability company (Gesellschaft mit beschränkter Haftung) supported by Deutsche Post World Net. The center is associated with the University of Bonn and offers a stimulating research environment through its research networks, research support, and visitors and doctoral programs. IZA engages in (i) original and internationally competitive research in all fields of labor economics, (ii) development of policy concepts, and (iii) dissemination of research results and concepts to the interested public. The current research program deals with (1) mobility and flexibility of labor, (2) internationalization of labor markets, (3) welfare state and labor market, (4) labor markets in transition countries, (5) the future of labor, (6) evaluation of labor market policies and projects and (7) general labor economics.

IZA Discussion Papers often represent preliminary work and are circulated to encourage discussion. Citation of such a paper should account for its provisional character. A revised version may be available on the IZA website (www.iza.org) or directly from the author. 


\section{ABSTRACT \\ Unemployment in the European Union: Institutions, Prices, and Growth*}

This paper presents a reappraisal of unemployment movements in the European Union. Our analysis is based on the chain reaction theory of unemployment, which focuses on (a) the interaction among labor market adjustment processes, (b) the interplay between these adjustment processes and the dynamic structure of labor market shocks, and (c) the interaction between the adjustment processes and economic growth. We divide the shocks into institutional variables, price variables, and growth drivers. Estimating a system of labor market equations for a panel of EU countries, we derive the dynamic unemployment responses to each shock. Our analysis permits us to distinguish between the short- and longrun effects of the shocks. Different shocks generate different degrees of "unemployment persistence" (responses to temporary shocks) and "unemployment responsiveness" (responses to permanent shocks). We find that the growth drivers play a dominant role in accounting for the main swings in EU unemployment.

JEL Classification: E30, E37, J32, J60, J64

Keywords: unemployment, natural rate, labor market shocks, chain reaction theory, employment, labor force participation, wage determination, dynamic contributions, homogeneous dynamic panels, panel unit root tests

Corresponding author:

Dennis Snower

Department of Economics

Birkbeck College

University of London

7 Gresse Street

London W1T 1LL

United Kingdom

Tel.: +442076316408

Fax: +44 2076316416

Email: DSnower@econ.bbk.ac.uk

\footnotetext{
* We gratefully acknowledge the financial support from the following sources: for all authors, IZA, Bonn, for the project on "Reappraising Europe's Unemployment Problem;" for Marika Karanassou, the ESRC Grant No.R000239139.
} 


\section{Introduction}

The two standard approaches to interpretting movements of unemployment in the E uropean Union are the "structural" and "hysteresis" approaches. The structural approach involves dividing unemployment into cyclical components (depicting business cycle variations, lasting a few years) and structural components (depicting longer-term movements), which are largely independent of one another. This mainstream view is often associated with the natural rate or NAIRU hypothesis. According to the hysteresis approach, the labor market equilibrium gets stuck at wherever it happens to be currently. Thus current unemployment is the best predictor of its future values, since it has a unit root. In this context, it is impossible to distinguish between structural and cyclical components, since each cyclical variation has long-term exects.

B oth approaches have had a rather uneasy relationship to the empirical facts. EU unemployment has drifted upwards in a series of big jumps coinciding largely with past recessions (those of the mid-1970s, the early 1980s, the early 1990s, and the early 2000s). While unemployment increased promptly with each recession, it has had a well-known tendency to remain high for considerable periods after the slump in product demand ended. This behavior is dic cult to explain within an analytical framework where structural and cyclical unemployment are largely independent of one another. At the other extreme, hysteresis combined with random shocks to unemployment implies that unemployment hits 0 or 100 percent with probability one in ..nite time - clearly a counterfactual implication.

This paper pursues a dixerent approach, that of the chain reaction theory of labor market activity. ${ }^{1}$ Here movements in unemployment are viewed as the cumulative outcome of prolonged adjustments to a stream of labor market shocks. The shocks may be temporary (such as oil price shocks) or permanent (such as changes in the level of productivity) or they may have a variety of other dynamic features (eg. AR or MA components); they may be anticipated or unanticipated by the labor market participants. The prolonged adjustments arise from adjustment costs, such as costs of hiring and ..ring, search costs, training costs, or costs of entering into and exiting from the labor force. Since the adjustments can be very prolonged - much longer than the standard business cycle variations - it is not appropriate to divide movements in unemployment into cyclical and structural components. But since the adjustments are not in..nitely long, hysteresis is not

\footnotetext{
${ }^{1}$ See, for example, Henry and Snower (1996), Henry, K ar anassou and Snower (2000), K ar anassou and Snower $(1998,2000)$.
} 
present.

It would be profoundly misleading to dismiss the chain reaction theory as merely an intermediate position between the structural and hysteresis approaches. In particular, the focus of the chain reaction theory (CRT) is dixerent from either in the following respects:

2 The CRT examines the temporal interactions among dixerent labor market adjustment processes. For example, it investigates whether prolonged adjustments in employment, wage setting, and labor force participation are complementary with one another in propagating temporary and permanent labor market shocks beyond the time spanned by business cycles. Such issues are not central to the structural approach, since it presumes that lagged adjustments die out after a few years. Nor does it play a signi..cant role in the hysteresis approach, since unemployment is there assumed to havea unit root regardless of what the underlying adjustment processes might be ${ }^{2}$

2 The CRT examines the interplay between the dynamic structure of the shocks and the characteristics of the adjustment processes. For example, it explores whether changes in adjustment processes that make the after-exects of temporary shocks more persistent also impart more inertia to the after-exects of permanent shocks. These matters lie outside the purview of the structural approach, which focuses primarily on the business cycle fuctuations generated by temporary shocks. The hysteresis approach al so focuses on temporary shocks, but now they are taken to have permanent exects. (Permanent shocks would lead to explosive labor market behavior under hysteresis.)

2 The CRT focuses on the interaction between economic growth and adjustment processes. In the presence of economic growth in thelab or market - e.g. growth of productivity leading to a steady rise in labor demand and growth in population leading to a steady rise in labor supply - thelagged adjustment processes never have a chance to work themselves out entirely. Under these circumstances, the equilibrium levels of unemployment are not the same as the frictionless equilibrium levels of unemployment. Rather, they depend

\footnotetext{
${ }^{2}$ Since the structural and hysteresis approaches downplay the temporal interactions among dixerent adjustment processes, labor market behavior is usually analyzed in terms of singleequation models (e.g. an unemployment equation). By contrast, the CRT analyzes it in terms of multi-equation models - comprising labor demand, labor supply, and wage setting behavior in order to depict distinct adjustment processes that interact with one another.
} 
on how far these levels remain behind their moving (frictionless) targets on account of the lagged adjustment processes.

This paper uses the CRT to explain EU unemployment in the following way. We begin by depicting EU labor markets through a system of equations, including a labor demand, wage setting, labor supply, production function, and unemployment equation. We estimate this system for a macro dynamic panel of EU countries. The panel of countries, together with cross-country restrictions on the adjustment processes, provide enough data points to enable us to distinguish between the unemployment exects of changes in our exogenous variables and those of the dynamic adjustments to these changes.

Then we use the estimated system to decomp ose the movements of EU unemployment into the dynamic responses to dixerent lab or market shocks. The shocks are changes in the exogenous variables of our system. These exogenous variables are divided into three groups: institutional variables, price variables and what we call growth drivers (viz., factors responsible for long-term economic growth).

Formally, let us begin with a few de..nitions:

De..nition A shock at period $t$ is the change in an exogenous variable $x_{i}$ from some ..xed point in time $\tau$ (base period) to period $t: s_{i t}=x_{i t} \mathbf{i} x_{i \tau}$, where $t, \tau$.

Thus, the deviation through time of each exogenous variable from its base period level is identi..ed with a time series of oneon shocks: $s_{i t}=x_{i t} \mathbf{i} x_{i \tau}$, $s_{i, t+1}=x_{i, t+1} \mathbf{i} \quad x_{i \tau}, s_{i, t+2}=x_{i, t+2} \mathbf{i} \quad x_{i \tau}, \ldots$

De..nition An unemployment response to a shock ${ }^{\mathbf{i}} u_{t+j}^{R}\left(s_{i t}\right), j, 0^{\Phi}$ is the change in the unemployment rate at period $t+j$ resulting from the period $t$ shock $s_{i t}$.

Each shock $s_{i t}$ leads to an intertemporal stream of unemployment responses: $u_{t}^{R}\left(s_{i t}\right), u_{t+1}^{R}\left(s_{i t}\right), u_{t+2}^{R}\left(s_{i t}\right), \ldots$ These unemployment responses may be derived by simulating our estimated system, deriving the responses of all endogenous variables, and then using the movements in these endogenous variables to derive the associated movements in unemployment.

De..nition The dynamic contribution of the exogenous variable $x_{i}$ to unemployment represents the response of unemployment at each point in time to all past and contemporaneous shocks associated with the exogenous variable $x_{i}$. 
Since each shock $s_{i t}$ in term period $t$ generates a stream of unemployment responses, $u_{t+j}^{R}\left(s_{i t}\right)$ for $j, 0$, the time series of shocks for each exogenous variable $x_{i}\left(s_{i t}, s_{i, t+1}, s_{i, t+2}, \ldots\right)$ is associated with a cumulated stream of unemployment responses: $u_{t}^{D C}\left(x_{i}\right)=u_{t}^{R}\left(s_{i t}\right), u_{t+1}^{D C}\left(x_{i}\right)=u_{t+1}^{R}\left(s_{i t}\right)+u_{t+1}^{R}\left(s_{i, t+1}\right), u_{t+2}^{D C}\left(x_{i}\right)=$ $u_{t+2}^{R}\left(s_{i t}\right)+u_{t+2}^{R}\left(s_{i, t+1}\right)+u_{t+2}^{R}\left(s_{i, t+2}\right), \ldots$ T hetimeseries $u_{t+j}^{D C}\left(x_{i}\right), j, 0$, constitutes the dynamic contributions of the exogenous variable $x_{i}$ to unemployment.

The aim of this paper is to reassess the driving forces underlying the swings in EU unemployment over the past three decades through an analysis involving the following steps: (i) identify salient groups of shocks, viz., institutional variables, price variables, and "growth drivers" (sources of economic growth), (ii) estimate a labor market system for the EU countries, (iii) use this system to generate the unemployment responses to the above shocks, and (iv) calculate the dynamic contribution of each exogenous variable to unemployment, thereby shedding new light on the evolution of $\mathrm{EU}$ unemployment.

The empirical assessment of how a particular set of exogenous variables inłuences EU unemployment depends signi..cantly on the intertemporal propagation channels we take into consideration. The estimated in $¥$ uence of our exogenous variables in the context above will turn out to be quite dixerent from that in the more st andard empirical setup, where these variables are depicted as inłuencing unemployment directly within a single unemployment equation. The resulting empirical assessment will show that the in $¥$ uence of shocks depends importantly on the temporal progation channels (consisting of the interrelated labor market adjustment processes).

We ..nd the growth drivers play a much more important role in accounting for the main swings in EU unemployment than the institutional or price variables. In the context of our dynamic model, the movements in EU unemployment may be understood in terms of the after-exects from temporary and permanent shocks to our exogenous variables. The after-exects of temporary shocks measure the degree of "unemployment persistence," whereas the after-exects of permanent shocks measure the degree of "unemployment responsiveness." Since dixerent exogenous variables enter dixerent labor market equations with dixerent dynamic characteristics, temporary shocks to dixerent exogenous variables are associated with dixerent degrees of unemployment persistence, and permanent shocks to dixerent exogenous variables generate dixerent degrees of unemployment responsiveness. These dynamic features help explain the movements of EU unemployment.

The paper is organized as follows. Section 2 outlines the structure of our model. Section 3 presents our empirical model for the EU. Section 4 presents the 
resulting analysis of the driving forces underlying the major movements in EU unemployment. Section 5 contrasts our results with those generated by a singleequation analysis of EU unemployment. Section 6 presents empirical impulse response functions. F inally, Section 7 condudes.

\section{Structure of the M odel}

We estimate a structural vector autoregressive distributed lag model for the EU countries: ${ }^{3}$

$$
\mathrm{A}(L) \mathbf{y}_{t}=\mathbf{B}(L) \mathbf{x}_{t}+\varepsilon_{t}, t=1,2, \ldots, T,
$$

where $L$ is the lag operator, $\mathrm{y}_{t}$ is a vector of endogenous variables, $\mathrm{x}_{t}$ is a vector of exogenous variables (including deterministic trends), $\varepsilon_{t}$ is a vector of identically independently distributed error terms, A and B are coec cient matrices, and

$$
\mathrm{A}(L)=\mathrm{A}_{0} \text { i } \mathrm{A}_{1} L \mathbf{i} \ldots \text { i } \mathrm{A}_{p} L^{p}, \mathrm{~B}(L)=\mathrm{B}_{0}+\mathrm{B}_{1} L+\ldots+\mathrm{B}_{q} L^{q} .
$$

The endogenous variables of our system are employment $\left(n_{t}\right)$, the labor force $\left(l_{t}\right)$, the real wage $\left(w_{t}\right)$, output $\left(q_{t}\right)$, and the unemployment rate $\left(u_{t}\right)$. All variables are national aggregates and all (except the unemployment rate) are in logarithms. The equation system (2.1) consists of ...ve equations:

2 a labor demand equation, describing the equilibrium employment,

2 a labor supply equation, describing the equilibrium size of the labor force,

2 a wage setting equation, describing real wage determination,

2 a production function, and

2 a de. nition of the unemployment rate (not in logs) $:^{4}$

$$
u_{t}=l_{t} \mathbf{i} n_{t} .
$$

${ }^{3}$ The dynamic system (2.1) is stable if, for given values of the exogenous variables, all the roots of the determinantal equation

$$
\mathrm{jA}_{0} \text { i } \mathrm{A}_{1} L \mathrm{i} \ldots \text {; } \mathrm{A}_{p} L^{p} \mathrm{j}=0
$$

lie outside the unit circle. $N$ ote that the estimated equations in Section 3 below satisfy this condition.

${ }^{4} \mathrm{Given}$ then the labor force and employment are in logarithms, this is an approximation. 
Substituting the estimated equations (2.1) into (2.2), and further algebraic manipulation, leads to the following ..tted "reduced form" unemployment rate equation: ${ }^{5}$

$$
u_{t}={ }_{j=1}^{X^{I}} \phi_{j} u_{t_{\mathrm{i}} j}+{ }_{j=0}^{\mathrm{X}^{J}} \theta_{j}^{0} \mathrm{x}_{\mathrm{ti}_{\mathrm{i}} j}, t=1,2, \ldots, T,
$$

where the autoregressive parameters $\phi$ and the vectors $\theta$ of the coet cients of the exogenous variables are functions of the estimated structural parameters of (2.1).

For expositional simplicity in explaining our decomposition of EU unemployment into dynamic contributions of exogenous variables, consider a simple model where the unemployment equation (2.3) is of ..rst order and the vector $x_{t}$ consists of the contemporaneous values of two exogenous variables, $x_{1 t}$ and $x_{2 t}$ :

$$
u_{t}=\phi_{1} u_{t i} 1+\theta_{1} x_{1 t}+\theta_{2} x_{2 t} .
$$

U sing backward substitution, we can express the unemployment rate in terms of its pre-sample value $u_{0}$ :

$$
u_{t}=\phi_{1}^{t} u_{0}+\theta_{1}{ }_{j=0}^{\boldsymbol{X}_{1}} \phi_{1}^{j} x_{1, t_{\mathrm{i}} j}+\theta_{2}{ }_{j=0}^{\boldsymbol{X}^{1}} \phi_{1}^{j} x_{2, t_{\mathrm{i}} j}, t=1,2, \ldots, T .
$$

In this context, we ..rst compute the base run unemployment rate ${ }^{\mathrm{i}} u_{t}^{B R}{ }^{\phi}$ by keeping the exogenous variables constant at their initial period $(t=1)$ levels throughout our span of analysis (i.e., $x_{1, t_{\mathrm{i}} j}=x_{11}$ and $x_{1, t_{\mathrm{i}} j}=x_{11}$ for $j=0, \ldots, t \mathbf{i}$ 1):

$$
u_{t}^{B R}=\phi_{1}^{t} u_{0}+\theta_{1}{ }_{j=0}^{X^{1}} \phi_{1}^{j} x_{11}+\theta_{2}{ }_{j=0}^{X^{1}} \phi_{1}^{j} x_{21} .
$$

We then subtract the base run values (2.6) from the unemployment rate equation (2.5) to identify the dynamic contributions of the exogenous variables in the

\footnotetext{
${ }^{5}$ The stability of each of the equations in the dynamic system (2.1) does not necessarily imply the stability of the reduced form unemployment rate equation (2.2). For the stability of the latter we need all the roots of the polynomial

$$
1 \text { i } \phi_{1} L \mathbf{i} \quad \ldots \text { i } \phi_{I} L^{I}=0
$$

to lie outside the unit circle. Note that our est imations in Section 3 below satisfy this condition.
} 
sample period:

$$
u_{t}^{D C}, u_{t} \mathbf{i} \quad u_{t}^{B R}=\theta_{1}{ }_{j=0}^{\boldsymbol{X}^{1}} \phi_{1}^{j}\left(x_{1, t_{\mathbf{i}} j} \mathbf{i} x_{11}\right)+\theta_{2}^{\boldsymbol{x}^{1}} \phi_{j=0}^{j}\left(x_{2, t_{\mathbf{i}} j} \mathbf{i} x_{21}\right) .
$$

We now decompose the above series into the dynamic contributions associated with the exogenous variable $x_{1}$ :

$$
u_{t}^{D C}\left(x_{1}\right)=\theta_{1}^{\boldsymbol{X}^{1}} \phi_{1=0}^{j}\left(x_{1, \mathrm{t}_{\mathrm{i}} j} \mathbf{i} x_{11}\right),
$$

and the dynamic contributions associated with the exogenous variable $x_{2}$ :

$$
u_{t}^{D C}\left(x_{2}\right)=\theta_{2}{ }_{j=0}^{X^{1}} \phi_{1}^{j}\left(x_{2, t_{i} j} \mathbf{i} x_{21}\right) .
$$

Equations (2.8)-(2.9) measure the exect of each exogenous variable on the unemployment trajectory relative to the base run. ${ }^{6}$

Therefore, the unemployment rate equation (2.5) can be seen as the sum of three components:

$$
u_{t}=u_{t}^{D C}\left(x_{1}\right)+u_{t}^{D C}\left(x_{2}\right)+u_{t}^{B R},
$$

i.e., the dynamic contributions of the exogenous variables and the base run unemployment rate.

N ext, we derive further in $\ddagger$ uences of the exogenous variables on unemployment:

2 The direct exect of an exogenous variable on unemployment is the contemporaneous exect, occurring before the lagged adjustments take place. Speci..cally, the direct ex ects of the exogenous variables $x_{1}$ and $x_{2}$ on unemployment are the initial dynamic contributions of these variables given by the ..rst terms on the right side of equations (2.8) and (2.9), respectively:

$$
u_{t}^{D E}\left(x_{1}\right)=\theta_{1}\left(x_{1 t} \mathbf{i} \quad x_{11}\right) \text { and } u_{t}^{D E}\left(x_{2}\right)=\theta_{2}\left(x_{2 t} \mathbf{i} x_{21}\right) .
$$

${ }^{6}$ It is important to note that this is simply a dynamic accounting exercise, answering the question: how much of the movement in unemployment can be accounted for by the movements in each of the exogenous variables. It does not tell us what would happen to unemployment if the exogenous variables followed dixerent trajectories, because in that event agents may change their behavior patterns and thus the parameters of our behavioral equations may change (in accordance with the Lucas critique). 
2 The frictionless contribution of an exogenous variable to unemployment measures how this variable would in uence unemployment if all temporal adjustment processes worked themselves out within each period of analysis. Speci..cally, the frictionless contribution of each exogenous variable is obtained by computing the steady state $\mathrm{e}^{7}$ of the unemployment equation (2.4), $u_{t}=\frac{\theta_{1} x_{1}+\theta_{2} x_{2 t}}{1_{\mathrm{i}} \phi_{1}}$, and subtracting from it the steady state unemployment when that exogenous variable remains constant at its initial period 1 value:

$$
u_{t}^{F C}\left(x_{1}\right)=\frac{\theta_{1}}{1 \mathbf{i} \phi_{1}}\left(x_{1 t} \mathbf{i} x_{11}\right) \text { and } u_{t}^{F C}\left(x_{2}\right)=\frac{\theta_{2}}{1 \mathbf{i} \phi_{1}}\left(x_{2 t} \mathbf{i} x_{21}\right) \text {. }
$$

Clearly, when the autoregressive order of the reduced form unemployment equation is one, as assumed in the above illustration, the frictionless contributions series of each exogenous variable represents a rescaling of its direct exects. However, the two measures will not be rescaled versions of one another in the more plausible case where the multi-equation model (2.1) reduces to an unemployment equation of autoregressive order greater than one. $^{8}$

\footnotetext{
${ }^{7}$ The steady state of a dixerence equation is derived by setting the lagged value of the endogenous variable equal to its current value.

${ }^{8}$ To demonstrate this result, consider the following two-equation model:

$$
\begin{gathered}
n_{t}=\alpha_{1} n_{t ;} 1+\beta_{1} x_{t}, \\
l_{t}=\alpha_{2} l_{t ;}+\beta_{2} x_{t} .
\end{gathered}
$$

R ecall that unemployment is de.ned as $u_{t}=l_{t} \mathbf{i} n_{t}$. The direct exects of the exogenous variable $x$ are thus given by

$$
\begin{array}{r}
u_{t}^{D E}(x)=\beta_{2}\left(x_{t} \mathbf{i} x_{1}\right) \mathbf{i} \beta_{1}\left(x_{t} \mathbf{i} x_{1}\right) \\
=\left(\begin{array}{lll}
\beta_{2} \mathbf{i} & \beta_{1}
\end{array}\right)\left(\begin{array}{ll}
x_{t} & x_{1}
\end{array}\right),
\end{array}
$$

and the frictionless contributions by

$$
\begin{array}{r}
u_{t}^{F C}(x)=\frac{\beta_{2}}{1 \mathbf{i} \alpha_{2}}\left(x_{t} \mathbf{i} x_{1}\right) \mathbf{i} \frac{\beta_{1}}{1 \mathbf{i} q^{11}}\left(x_{t} \mathbf{i} x_{1}\right) \\
=\frac{\beta_{2}}{1 \mathbf{i} \alpha_{2}} \mathbf{i} \frac{\beta_{1}}{1 \mathbf{i} \alpha_{1}}\left(x_{t} \mathbf{i} x_{1}\right) .
\end{array}
$$

The above shows that, in a multi-equation system, unless we impose the implausible assumption of identical autoregressive coed cients, the frictionless contributions are not equivalent to a rescaling of the direct exects of the exogenous variables.
} 
We now proceed to estimate the above in $¥$ uences and thereby glean new insights into what drives the movements in EU unemployment.

\section{The Empirical Model}

We have estimated a structural dynamic homogeneous panel data model comprising four equations plus the de..nition of the unemployment rate. ${ }^{9} \mathrm{O}$ ur empirical model includes eleven out of the ..fteen EU countries (A ustria, Belgium, Denmark, Germany, Finland, France, Italy, N etherlands, Spain, Sweden and the United Kingdom). (T he other four - Greece, I reland, Luxembourg and Portugal - had to be excluded on account of data limitations.) The model is estimated on annual OECD data for the period 1970-1999. Table 1 provides the de..nitions of the endogenous and exogenous variables.

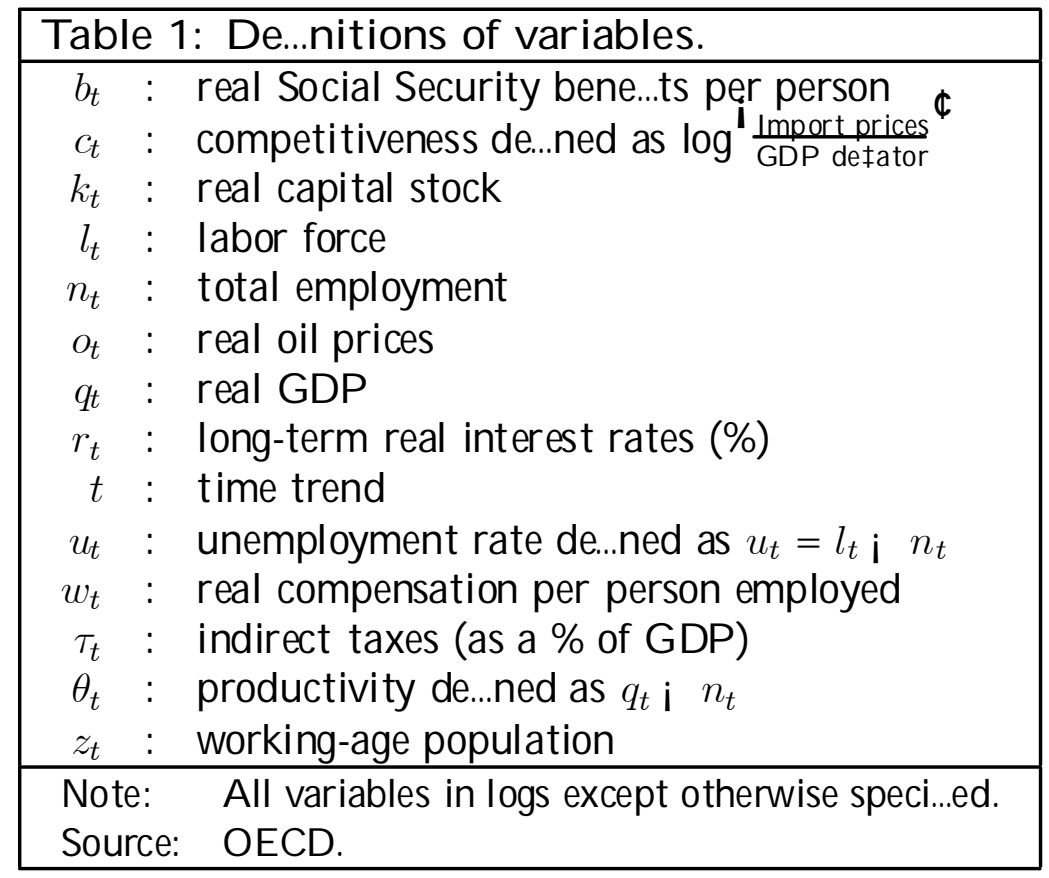

In estimating the model, we pool the observations across these countries, capturing cross-count ry dixerences only through ...xed exects (i.e. dixering constants

\footnotetext{
${ }^{9} \mathrm{~A}$ broader description of the methodology underlying dynamic panel data estimation is provided in K aranassou, Sala and Snower (2003). Here we out line only the main features of our estimation procedure.
} 
in the estimated equations). Pooling has the advantage of increasing the et ciency of the econometric estimates and thus provides a closer understanding of the adjustment mechanisms in dynamic relationships (see Hsiao (1986) and Baltagi (1995)). ${ }^{10}$ O ur ..xed-exect model is empirically preferred to heterogenous models containing individual country estimations, as indicated below.

O ne of the challenges of estimating dynamic panel data models is a correct speci...cation of the long-run relationships between the variables. In order to check if it is appropriate to use stationary panel data estimation techniques, we conduct a series of unit root tests.

The use of pooled data can generate more powerful unit root tests than the popular Dickey-Fuller (DF), A ugmented DF and Phillips-P erron (PP) tests. In our empirical analysis, to test for panel unit roots we have used the statistic proposed by Maddala and Wu (1999), which is an exact nonparametric test based on Fisher (1932):

$$
\lambda=\mathrm{i} 2{ }_{i=1}^{X^{N}} \ln \pi_{i} \gg \chi^{2}(2 N),
$$

where $\pi_{i}$ is the probability value of the ADF unit root test for the $i$ th unit (country). The results of this test, displayed in table 2, indicate that we can indeed proceed with stationary pane data estimation techniques.

\begin{tabular}{|c|c|c|c|c|c|}
\hline \multicolumn{6}{|c|}{ Table 2: Panel U nit Root Tests. } \\
\hline$\lambda\left(n_{i t}\right)$ & $=\quad 36.10$ & $\lambda\left(l_{i t}\right)$ & $=35.12$ & $\lambda\left(z_{i t}\right)$ & 40.57 \\
\hline$\lambda\left(q_{i t}\right)$ & 42.88 & $\lambda\left(r_{i t}\right)$ & $=47.67$ & $\lambda\left(b_{i t}\right)$ & 91.45 \\
\hline$\lambda\left(k_{i t}\right)$ & 41.19 & $\lambda\left(o_{i t}\right)$ & $=42.67$ & $\lambda\left(\tau_{i t}\right)$ & 46.24 \\
\hline$\lambda\left(w_{i t}\right)$ & 159.79 & $\lambda\left(c_{i t}\right)$ & 46.79 & & \\
\hline Notes: & \multicolumn{5}{|c|}{$\begin{array}{l}\lambda(\Phi \text { is the test proposed by Maddala and Wu (1999). } \\
\text { The test follows a chi-square (22) distribution. } \\
\text { The } 5 \% \text { critical value is approximately } 34 .\end{array}$} \\
\hline
\end{tabular}

To decide whether it is appropriate to use pooled equations, we sel ect between each of the pooled equations and the corresponding individual regressions by using the Schwarz Information Criterion (SIC) as suggested by Smith (2000). We compute the model selection criteria as follows:

$$
S I C_{\text {pooled }}=M L L \mathbf{i} \quad 0.5 k_{\text {pooled }} \log (N T) \text {, }
$$

\footnotetext{
${ }^{10}$ Banerjee (1999), B altagi and $\mathrm{K}$ ao (2000) and Smith (2000) provide an overview of dynamic panel data estimation techniques and nonstationary panel time series models.
} 


$$
S I C_{\text {individual }}={ }_{i=1}^{\mathrm{X} 1} M L L_{i} \mathbf{i} N\left[0.5 k_{i} \log (T)\right],
$$

where $M L L_{\text {pooled, }} M L L_{i}$ denote the maximum log likelihoods of the pool ed model and the $i$ th country time series regression, respectively; $k_{\text {pooled }}$ is the number of parameters estimated in the ..xed exects model (i.e. number of explanatory variables plus the 11 country speci..c exects), and $k_{i}$ is the number of parameters estimated in the individual country time series regression (i.e. number of explanatory variables plus an intercept); $N$ and $T$ denote the number of countries and estimation period, respectively. The model that maximizes the $S I C$ is preferred. A s table 3 shows, the results indicate that the ..xed exects model is preferred for all our four behavioral equations:

\begin{tabular}{|c|c|c|c|}
\hline & $S I C_{\text {pooled }}$ & & $\begin{array}{c}\text { individual } \\
\text {. }\end{array}$ \\
\hline Labor Demand: & 1051.25 & $>$ & 1032.12 \\
\hline Wage Setting: & 851.83 & $>$ & 810.05 \\
\hline Labor Force: & 1096.94 & $>$ & 1089.98 \\
\hline Production Function: & 972.48 & $>$ & 862.59 \\
\hline $\begin{array}{cc}\text { Notes: } & \text { The statistics } \\
& \text { The model tha } \\
\end{array}$ & ecc & & $\begin{array}{l}\text { and (3.3). } \\
\text { riterion is }\end{array}$ \\
\hline
\end{tabular}

Thus, we estimate a stationary dynamic panel, which is homogeneous and yields consistent ..xed exects estimators for the $11 \mathrm{EU}$ countries considered. ${ }^{11}$

Table 4 presents the estimated equations:

\footnotetext{
${ }^{11}$ The lag structure of the model was chosen on the basis of the A kaike and Schwarz model selection criteria.
} 


\begin{tabular}{|c|c|c|c|c|c|c|c|}
\hline \multicolumn{8}{|c|}{ Table 4: The EU model. 1970-1999. } \\
\hline \multicolumn{4}{|c|}{ Dependent variable: $n_{t}$} & & ec cient & St. e. & Prob. \\
\hline$n_{t_{\mathrm{j}} 1}$ & 1.42 & 0.039 & 0.000 & $w_{t \mathrm{i} 1}$ & 0.97 & 0.051 & 0.000 \\
\hline$n_{t \mathrm{i} 2}$ & ¡ 0.48 & 0.035 & 0.000 & $w_{t \mathrm{i}} 2$ & i 0.14 & 0.045 & 0.002 \\
\hline$w_{t}$ & i 0.03 & 0.012 & 0.011 & $u_{t}$ & i 0.29 & 0.045 & 0.000 \\
\hline$k_{t}$ & 0.02 & 0.009 & 0.035 & $\theta_{t}$ & 0.50 & 0.056 & 0.000 \\
\hline$\$ k_{t}$ & 1.99 & 0.070 & 0.000 & $\theta_{t_{\mathrm{i}} 1}$ & i 0.36 & 0.052 & 0.000 \\
\hline$\$ k_{t ; 1}$ & i 1.65 & 0.093 & 0.000 & $b_{t}$ & 0.14 & 0.020 & 0.000 \\
\hline$c_{t}$ & 0.02 & 0.006 & 0.003 & $b_{t \mathrm{i} 1}$ & i 0.12 & 0.022 & 0.000 \\
\hline$r_{t}$ & ¡ 0.001 & 0.000 & 0.019 & $o_{t}$ & 0.005 & 0.002 & 0.020 \\
\hline \multirow[t]{2}{*}{$t$} & 0.001 & 0.000 & 0.044 & $\tau_{t}$ & i 0.59 & 0.180 & 0.001 \\
\hline & & & & $\tau_{t \mathrm{i} 1}$ & 0.41 & 0.189 & 0.030 \\
\hline$R^{2}$ & 0.999 & & & $R^{2}$ & 0.999 & & \\
\hline$M L L$ & 1108.9 & & & $M L L$ & 912.0 & & \\
\hline \multicolumn{4}{|c|}{ Dependent variable: $l_{t}$} & \multicolumn{4}{|c|}{ Dependent variable: $\$ q_{t}$} \\
\hline & Coeф cient & St. e. & Prob. & & ec cient & St. e. & Prob. \\
\hline$l_{t_{\mathrm{i}} 1}$ & 1.00 & 0.031 & 0.000 & $q_{t_{\mathrm{i}} 2}$ & i 0.25 & 0.025 & 0.000 \\
\hline$l_{t_{\mathrm{i}} 2}$ & i 0.08 & 0.026 & 0.005 & $k_{t}$ & 0.02 & 0.013 & 0.095 \\
\hline$u_{t}$ & ¡ 0.04 & 0.019 & 0.060 & $n_{t}$ & 0.09 & 0.019 & 0.000 \\
\hline$\$ u_{t}$ & i 0.21 & 0.037 & 0.000 & $o_{t}$ & ¡ 0.004 & 0.002 & 0.047 \\
\hline$w_{t}$ & i 0.06 & 0.025 & 0.019 & $t$ & 0.004 & 0.001 & 0.000 \\
\hline$w_{t \mathrm{i} 1}$ & 0.05 & 0.025 & 0.039 & & & & \\
\hline$z_{t}$ & 1.11 & 0.037 & 0.000 & & & & \\
\hline$z_{t_{\mathrm{i}} 1}$ & i 1.00 & 0.043 & 0.000 & & & & \\
\hline$R^{2}$ & 0.999 & & & $R^{2}$ & 0.999 & & \\
\hline$M L L$ & 1151.4 & & & $M L L$ & 1019.1 & & \\
\hline
\end{tabular}

As we can see, the labor demand depends negatively on the real wage and the real interest rate, and positively on the level and the growth rate of capital stock; it also depends positively on competitiveness, which is de..ned as the ratio of the import price to the GDP defator, and on a linear trend. Real wages depend negatively on the unemployment rate and the indirect tax rate (as a ratio to 
GDP), and positively on productivity, social security bene..ts and oil prices. The labor force depends negatively on the level and growth of the unemployment rate and wages, whereas working-age population has a positive sign. ${ }^{12}$ The production function is standard, with a positive relationship of output with respect to employment, capital stock and a time trend (to capture technological progress).

F igure 1 indicates that the model tracks the actual unemployment rate remarkably well, despite the cross-country restrictions on the coed cients of the right-hand side variables:

\footnotetext{
${ }^{12}$ This relationship is restricted to be 1 in the long-run, which is not rejected by a Wald test.
} 
Figure 1: Actual and fitted values of the EU unemployment rates.

EU

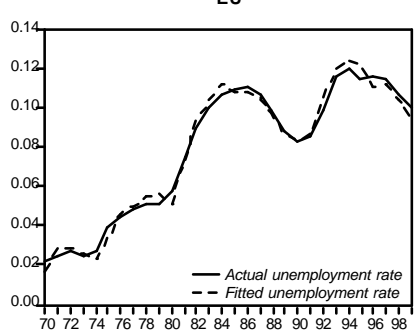

Denmark

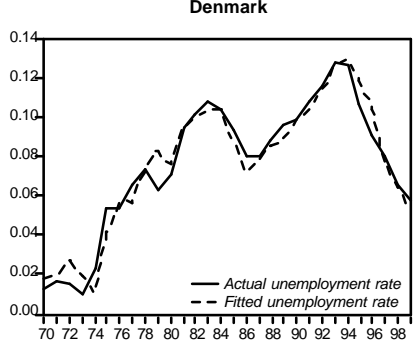

Germany

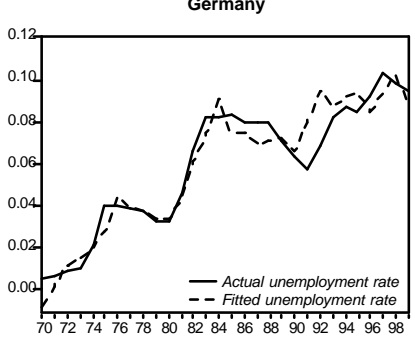

Spain

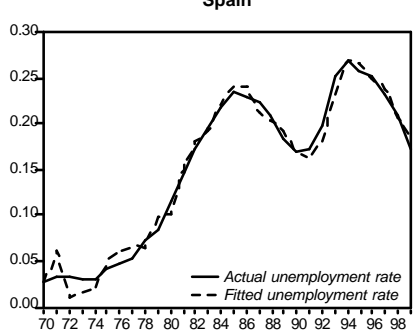

Austria
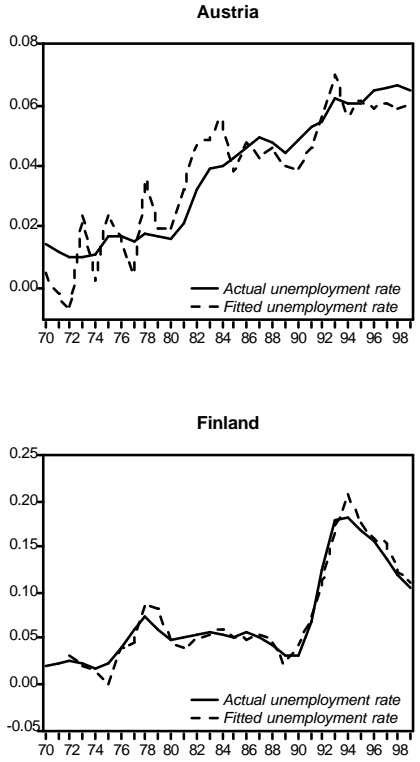

Italy

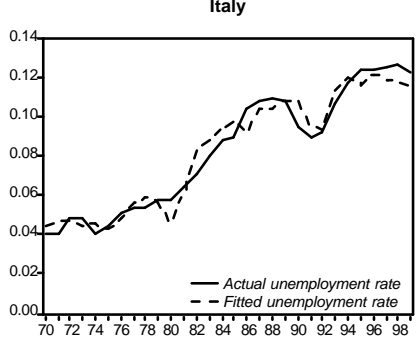

Sweden

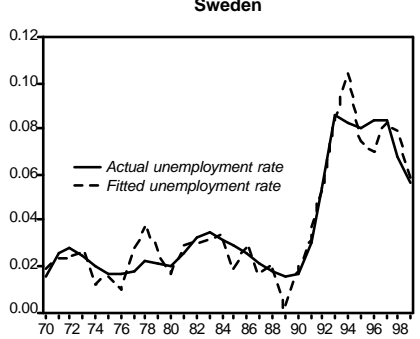

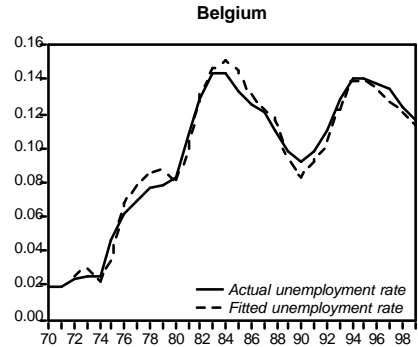

France

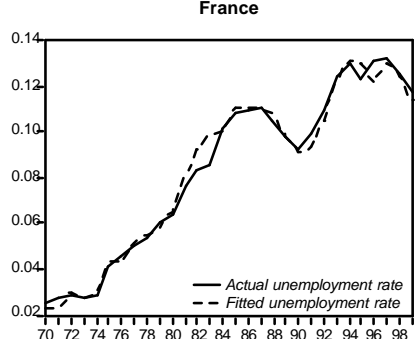

Netherlands

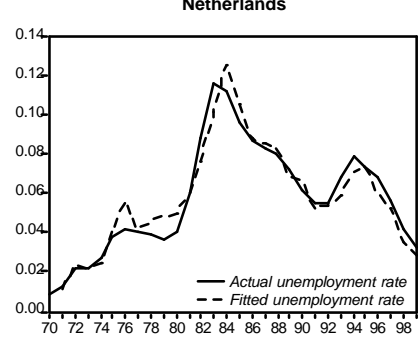

United Kingdom

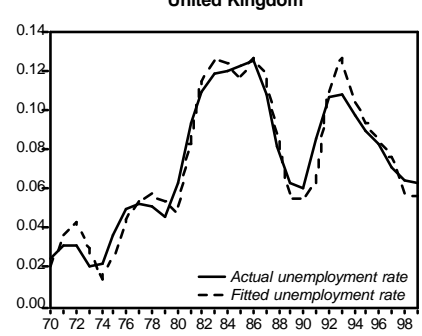




\section{Revisiting the Causes of European U nemployment}

On the basis of the empirical model above, we now examine the driving forces underlying $\mathrm{EU}$ unemployment by deriving the dynamic contributions of our exogenous variables. We divide these exogenous variables int o three groups:

1. institutional variables: social security bene..ts and indirect taxes,

2. prices: competitiveness, interest rates and oil prices; and

3. growth drivers: capital stock, technological change and working-age population

Figures 2 to 4 depict the direct exects of each exogenous variable (or group of exogenous variables), as well as their dynamic and frictionless unemployment contributions.

On account of the lagged adjustment processes in our model, the direct unemployment exects $\left(u_{t}^{D E}\left(x_{i}\right)\right)$ of each exogenous variable $\left(x_{i t}\right)$ give rise to smooth unemployment dynamic contributions $\left(u_{t}^{D C}\left(x_{i}\right)\right)$ in contrast with the frictionless contributions $\left(u_{t}^{F C}\left(x_{i}\right)\right)$.

\subsection{Contributions of the Institutional Variables}

The left-hand panels of Figures 2 compare the direct exects with the dynamic contributions of the inst itutional variables, whereas the right-hand panels compare the direct exects with the frictionless contributions of these variables. Figures $2 a$ and $2 \mathrm{~b}$ describe the infuence of both institutional variables together, whereas the remaining ..gures deal with social security contributions and indirect taxes separately.

F igure $2 c$ shows that social security bene..ts have pushed up the EU unemployment rate by larger and larger amounts, amounting to an increase of 3.4 percentage points over our sample period. They have had a progressively increasing negative inłuence on EU employment, and a smaller negative inłuence on the EU labor force (via their infuence on wages and unemployment).

A comparison of Figures $2 \mathrm{c}$ and $2 \mathrm{~d}$ highlights the role of lagged adjustment processes in modifying the inłuence of social security bene..ts through time. In Figure $2 \mathrm{c}$ we see that social security bene..ts had a pronounced positive direct exect on unemployment in the ..rst half of the 1970s, which stabilized over much 
of the sample period thereafter; however, the unemployment contributions of social security bene.ts, as noted, rise steadily over the entire sample period.

$\mathrm{F}$ igure $2 \mathrm{e}$ indicates that the contribution of indirect taxes to unemployment rate have been close to nill. Observe that in our model indirect taxes axect employment and the labor force only via their positive inłuence on the real wage. Most countries in our panel did not experience signi..cant variations in indirect taxes (as a ratio of GDP); the only exceptions were France and Spain, which encountered changes in opposite directions, thus roughly cancelling each other out on the aggregate EU level. 
Figure 2. Institutional variables.

Dynamic contributions, direct effects

and frictionless contributions.

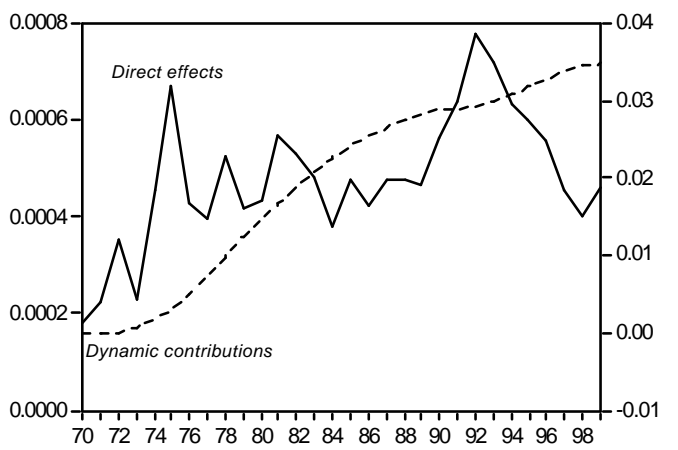

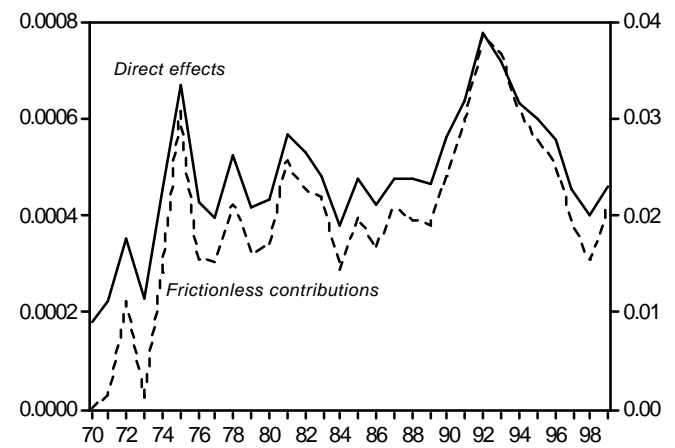

c.

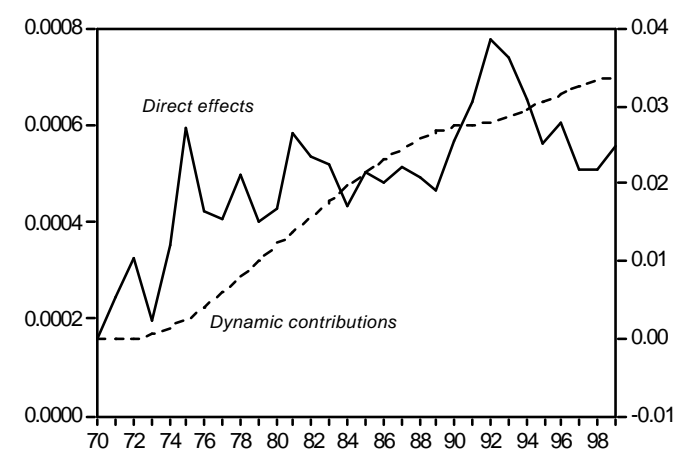

d.

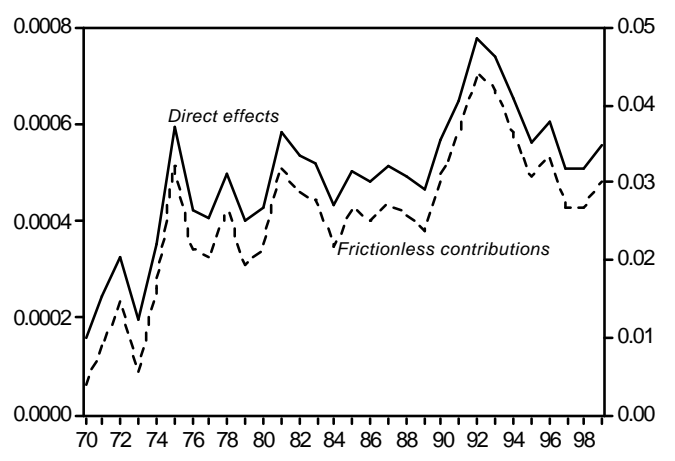

e.

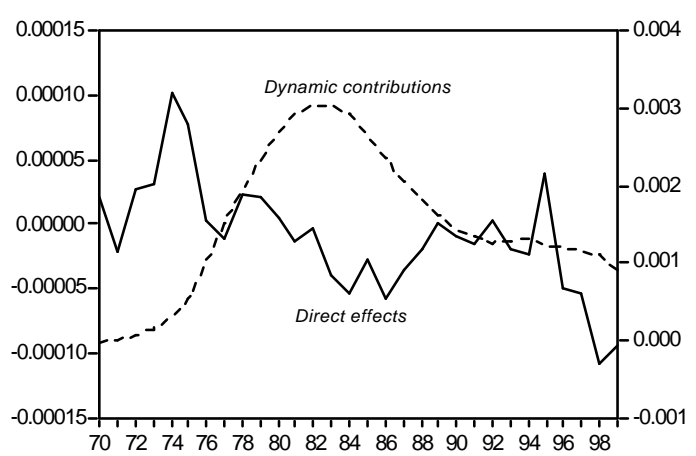

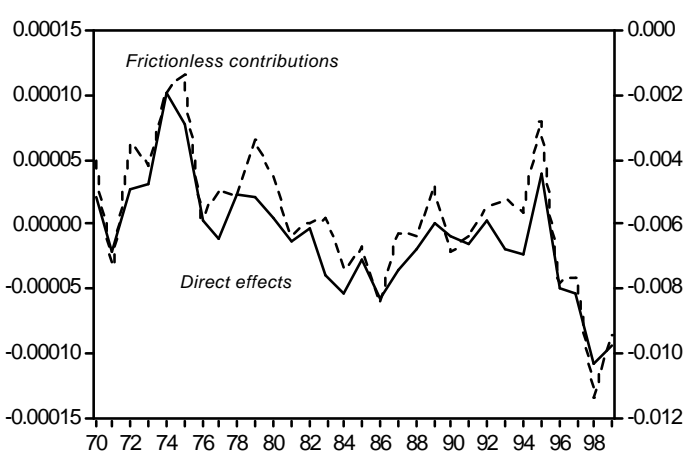




\subsection{Contributions of Prices}

Figures 3 describe the in $¥$ uences of the price variables.

F igure $3 c$ pictures the role of competitiveness (given the real oil price which is a separate exogenous variable). In our model, a rise in competitiveness (de..ned as the ratio of import prices to the GDP dełator) raises employment, presumably through import substitution. This, in turn, axects the real wage, which in $¥ u$ ences both employment and the lab or force. The ..gure shows that the rise in E U competitiveness reduced unemployment through the second half of the 1970s and 1980s, and the fall in EU competitiveness (possibly linked to the EU's disappointing productivity performance and rate of capital accumumlation) stimulated unemployment signi..cantly in the 1990 s.

$\mathrm{F}$ igure 3 e shows the role of the long-term real interest rate (given the capital stock, which is a separate exogenous variable). Similarly to competitiveness, the in uence of the real interest rate on unemployment operates primarily through employment (rather than the lab or force). From 1970 to 1983, interest rate movements have reduced unemployment (reaching a maximum of a 1 percentage point reduction in 1978 and 1979), but with the general shift towards tigher monetary policy, they stimulated unemployment thereafter (reaching a maximum of nearly 2 percentage points in 1996).

A comparison of $\mathrm{F}$ igures $3 e$ and $3 f$ suggests that movements in the real interest rate axect unemployment with signi..cant lags. The direct unemployment exects of the real interest rate reached a trough in 1975, and fell to zero by 1980; but the associated dynamic contributions reached a trough only in 1978, and fell to zero by 1984 . The direct unemployment exects were positive and roughly stable throughout the 1980s and ..rst half of the 1990s; but the associated dynamic unemployment contributions rose gradually from 1984 to 1996.

F inally, Figure $3 \mathrm{~g}$ shows a small in $\neq$ uence of the oil price on unemployment, contrary to many other studies. In part, the small magnitude may be due to the fact that the infuence is assessed for a given capital stock and competitiveness (which are other exogenous variables). The oil price shocks of the mid-1970s and early 1980s undoubtedly reduced capital formation and axected competitiveness. In part, some of what we estimate to be the delayed unemployment contributions of movements in competitiveness and the capital stock are commonly ascribed to the oil price 
Figure 3. Price variables.

Dynamic contributions, direct effects and frictionless contributions.

a. Price variables b.

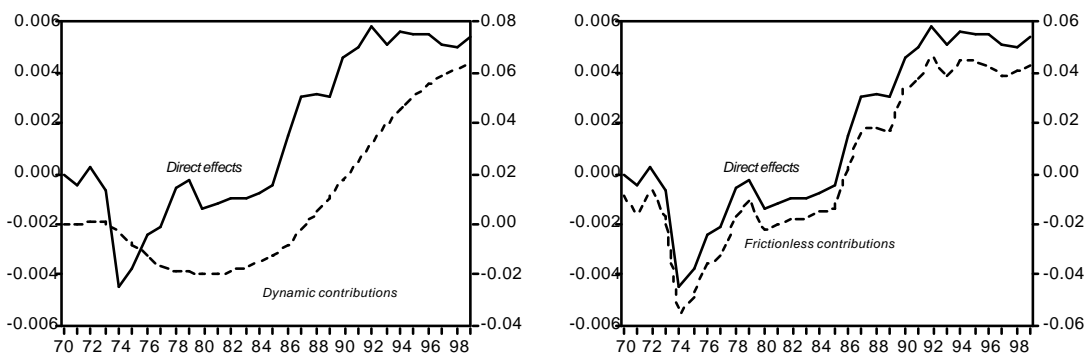

c.

Competitiveness
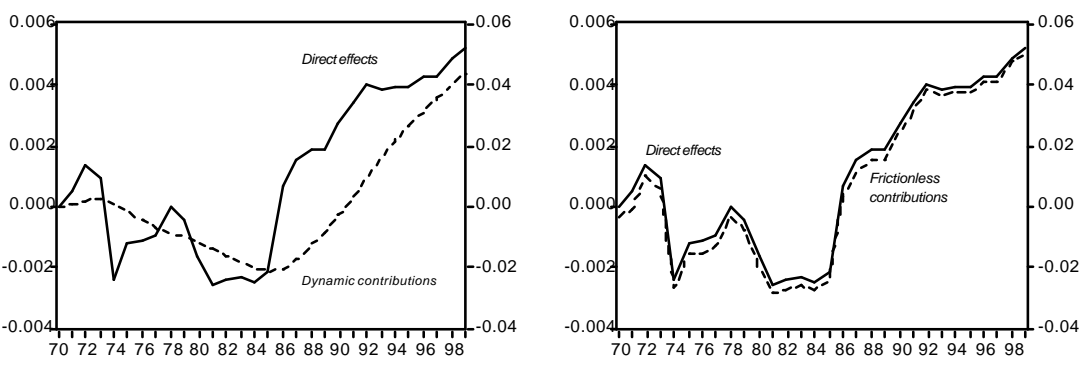

Interest rates
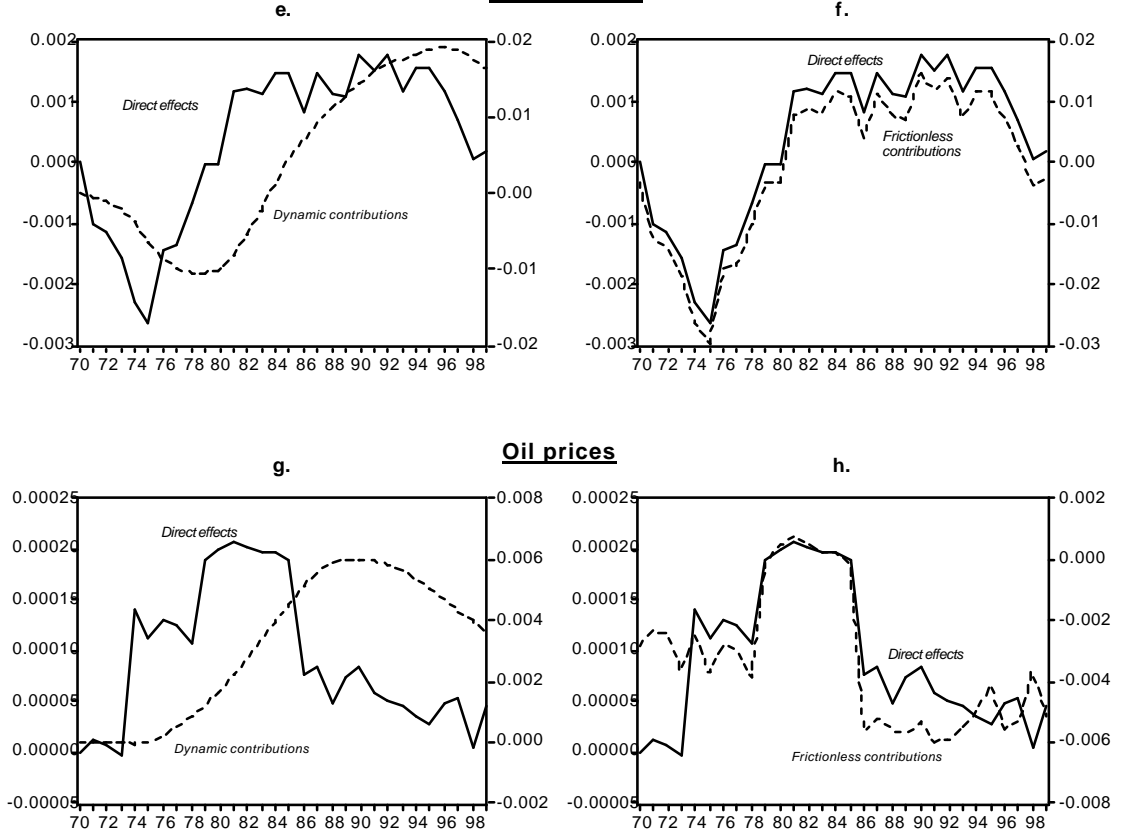


\subsection{Contributions of the Growth Drivers}

Figures $4 \mathrm{c}$ and $4 \mathrm{~g}$ suggest that two of our growth drivers - the capital stock and working age population - play a dominant role in accounting for movements in EU unemployment, with the capital stock being the more important. The ..gures show the unemployment contributions to be very large, but one must keep in mind that it is quite unrealistic to imagine that the capital stock would grow as it did if the working-age population were constant (implicitly assumed in Figure 4c, since the unemployment contributions are assessed for a given population). Thus it is more informative to examine the unemployment contributions from its combined inłuence, as shown in Figure 4a. 
Figure 4. Growth drivers.

Dynamic contributions, direct effects and frictionless contributions.

Growth drivers

b.

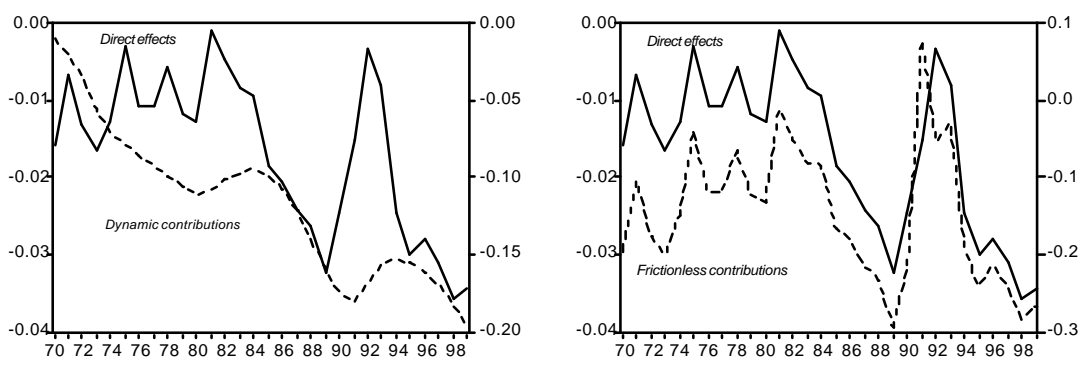

Capital stock

d.
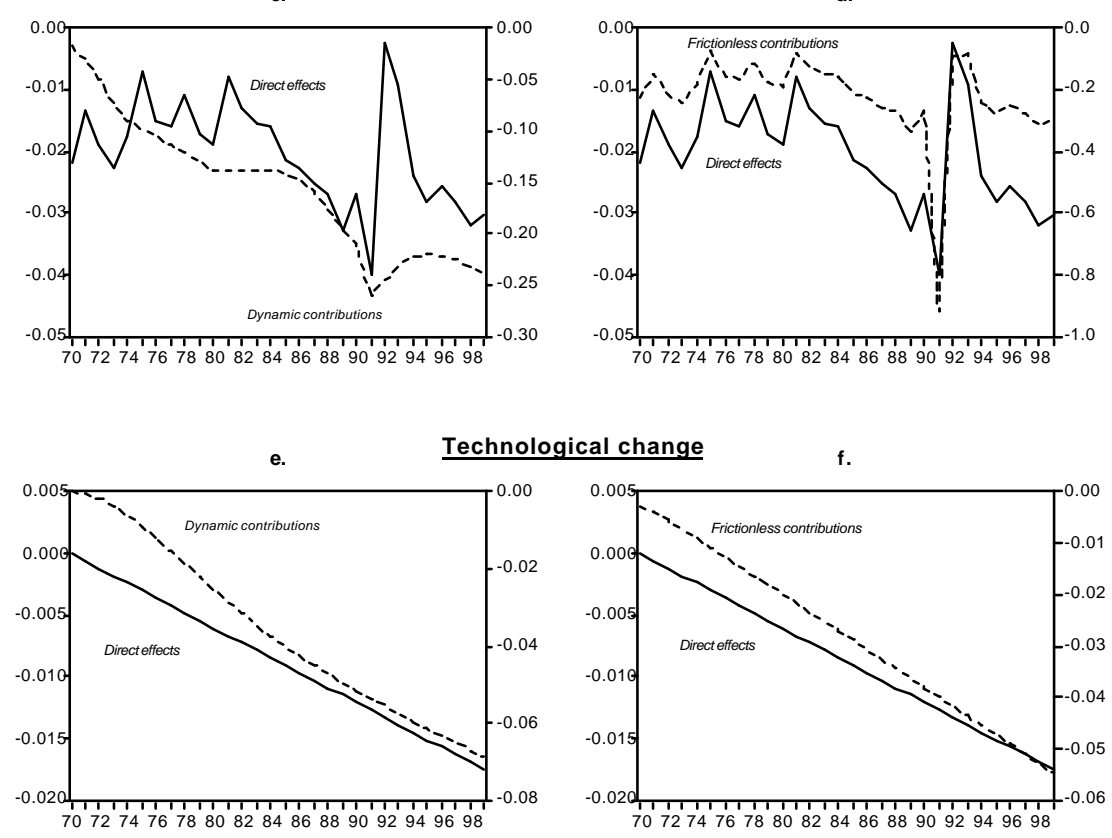

g. Working-age population
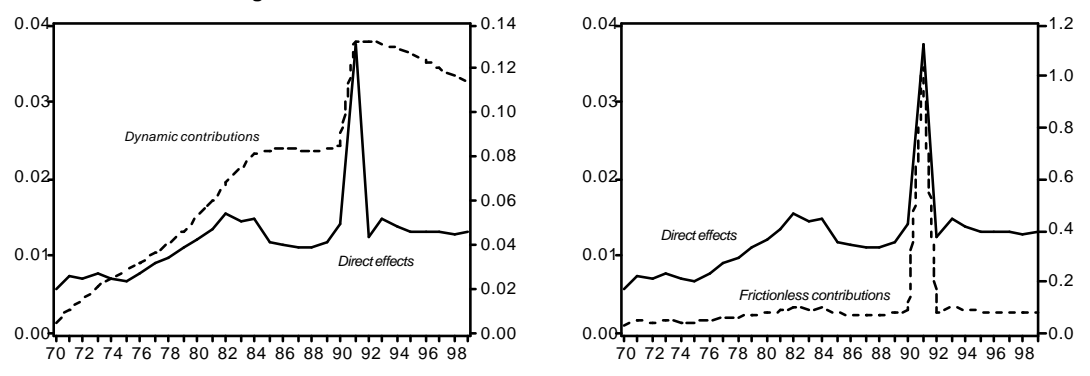
The powerful infuence of the capital stock and working-age population on EU unemployment is underscored Figure 5, which shows the dynamic unemployment contributions for dixerent growth rates of capital stock and working-age population.

Figure 5. Dynamic contributions under different growing scenarios

a. Capital stock

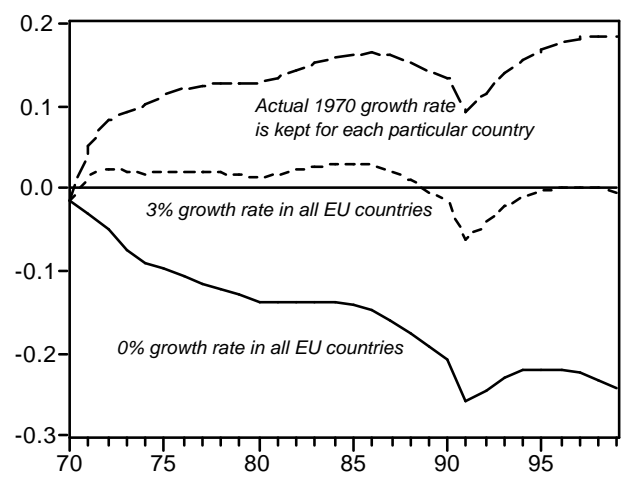

b. Working-age population

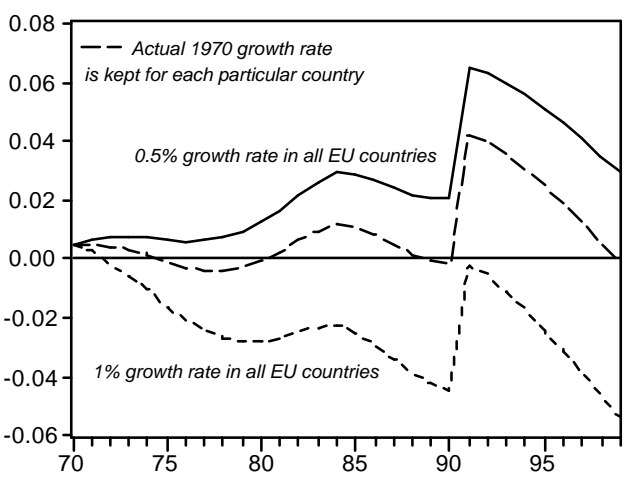

\section{Single versus M ulti-equation Models}

M ost empirical studies on the causes of unemployment are conducted in terms of single, aggregate unemployment equations. These equations are interpretted as reduced forms that are meant to summarize the behavior of multi-equation labor market systems, such as the one presented above. The open question is whether single-equation models are a good proxy for their multi-equation counterparts in a dynamic context. Karanassou, Sala, and Snower (2003) have shown that when the individual equations in a multi-equation system do not have the same regressors, the multi-equation models cannot be aggregated into single-equation models. How important is this limitation in explaining $\mathrm{EU}$ unemployment?

Naturally, single- and multi-equation models of unemployment both have their strengths and weaknesses. Theoretically, the single-equation models are simply aggregated summaries of the multi-equation counterparts. Empirically, multiequation models require more data to be estimated and thus are associated with lower degrees of freedom. In this paper, we have sought to overcome this diф culty by pooling country data across the EU. Thus our model may be a useful tool in 
exploring whether single-equation models deliver biased summaries of their multiequation underpinnings. Addressing this question can shed light on whether the dixerence between our analysis of EU unemployment and those in the conventional literature (e.g. Layard, Nickell and J ackman (1991), P helps (1994), P helps and Zoega (1998)) may be due single- versus multi-equation modeling.

Table 5 presents a version of a single-equation model where four out of the seven exogenous variables present in the multi-equation system are considered. (The other exogenous variables were statistically insigni..cant.) E ven though the interest rate is marginally signi ..cant, it is retained to provide a better speci..cation of the mode. ${ }^{13}$

\begin{tabular}{|c|c|c|c|}
\hline \multicolumn{4}{|c|}{ Table 5: Single-equation model. } \\
\hline \multicolumn{4}{|c|}{ Dependent variable: $u_{t}$} \\
\hline & Coed cient & St. e. & Prob. \\
\hline$u_{t \mathrm{i} 1}$ & 1.23 & 0.05 & 0.00 \\
\hline$u_{t \mathrm{i} 2}$ & i 0.51 & 0.04 & 0.00 \\
\hline$k_{t}$ & ¡ 0.014 & 0.01 & 0.02 \\
\hline$\$ k_{t}$ & i 0.37 & 0.06 & 0.00 \\
\hline$r_{t}$ & 0.024 & 0.019 & 0.21 \\
\hline$b_{t}$ & 0.02 & 0.01 & 0.00 \\
\hline$z_{t}$ & 0.18 & 0.04 & 0.00 \\
\hline$z_{t \mathrm{i} 1}$ & i 0.13 & 0.04 & 0.00 \\
\hline$R^{2}$ & 0.979 & & \\
\hline$M L L$ & 1081.1 & & \\
\hline
\end{tabular}

F igure $6 a$ describes the dixerences in the unemployment contributions derived from the single- and the multi-equation analysis. Observe that social security bene.ts - commonly considered one of the main sources of EU unemployment in the mainstream literature (e.g. Layard, Nickell and J ackman (1991), Blanchard

\footnotetext{
${ }^{13}$ This speci..cation allows a comparison with at least one variable belonging to each of the groups we have already distinguished: social security bene.ts, in the institutional variables group; interest rates, in the prices group; and, both, capital formation and working-age population as growth drivers.

The signi..cance of interest rates at the $21 \%$ size of the test (large with respect to the standard $5 \%$ or $10 \%$ ) axects only marginally the magnitude of the coet cient. Thus, the central conclusions from our decomposition analysis would remain substantially intact at a lower size of the test.
} 
and Wolfers (2000) - have a much greater in $¥$ uence on unemployment in the singleequation model than in the multi-equation system.

Interest rates have al so been assigned a major role in explaining the rise of EU unemployment over the 1980s and ..rst part of the 1990s (e.g. Phelps (1994) and $P$ helps and Zoega (1998 and 2001)). Figure 6b shows our multi-equation model assigns a more important role to the interest rates than the corresponding singleequation model does. It is worth recalling, moreover, that our multi-equation model aims to capture only that part of the infuence of interest rates that operates independently of the capital stock, the working-age population, and our other exogenous variables. In the single-equation modes, on the other hand, the capital stock and working-age population usually do not appear, since the latter are trended variables whereas unemployment is untrended.

F igures $6 \mathrm{c}$ and $6 \mathrm{~d}$ show that when the capital stock and working-age population are included as explanatory variables in the single-equation model, the capital stock plays a much smaller role for EU unemployment than in our multi-equation model, whereas population plays a much larger role.

In short, our analysis suggests that single-equation models may indeed provide a biased account of EU unemployment, in $¥$ ating the role of institutional variables and underplaying the role of the growth drivers. 
Figure 6: Dynamic contributions of different exogenous variables: Multi-equation versus single-equation results

a. Social security benefits

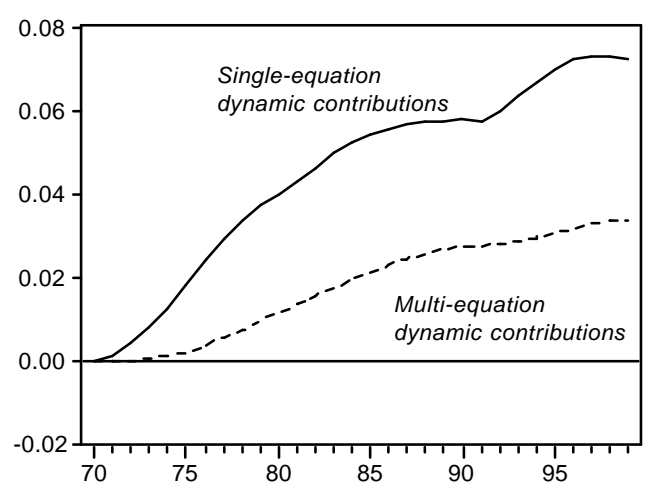

c. Capital stock

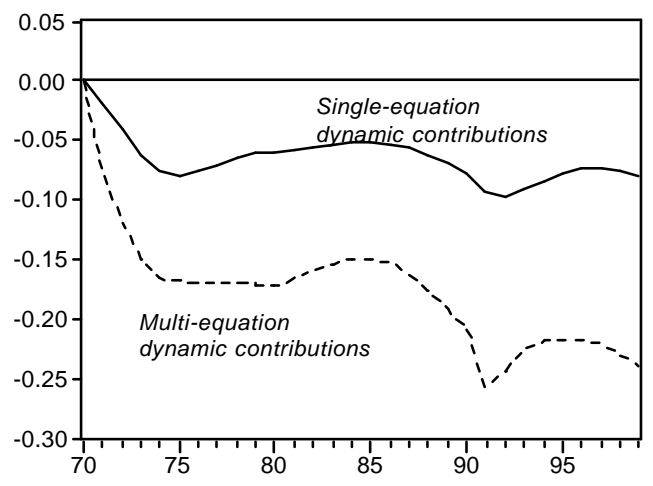

b. Interest rates

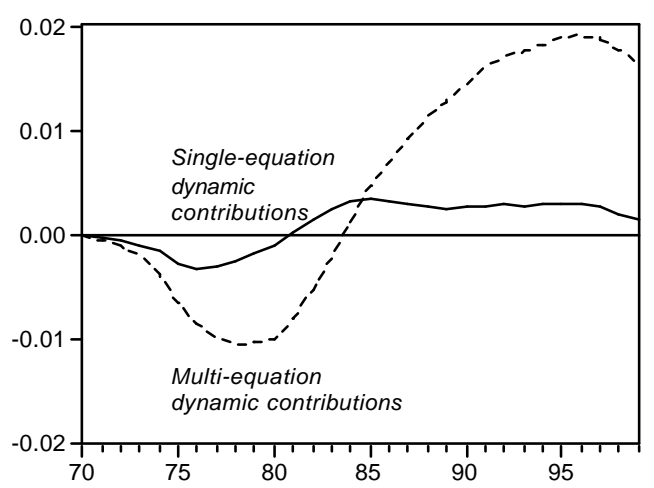

d. Working-age population

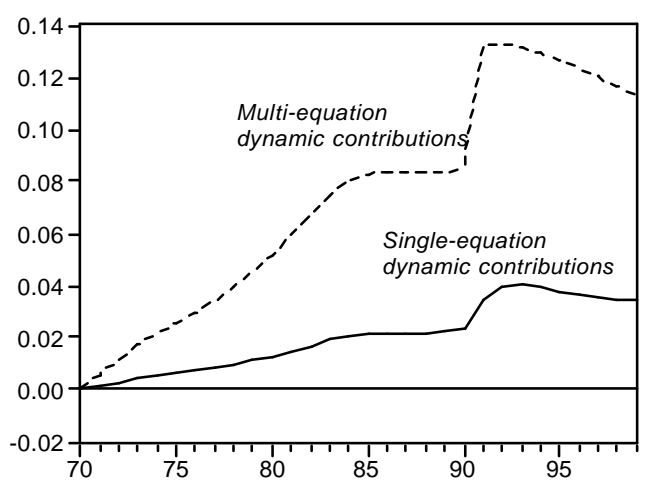

\section{Exects of Temporary and Permanent Shocks}

In this section we construct aggregative measures of the dynamic unemployment responses to temporary and permanent shocks. ${ }^{14}$ Speci..cally, we consider two such inł uences:

2 (i) the persistent unemployment exects of temporary shocks, called unemployment persistence, and

\footnotetext{
${ }^{14}$ For a detailed discussion of these measures see Karanassou and Snower (1998).
} 
2 (ii) the delayed unemployment exects of permanent shocks, called unemployment responsiveness.

A temporary shock $(T S)$ is identi..ed as a one ox unit increase in an exogenous variable at time $t$, assuming that all other exogenous variables remain unchanged. Due to the labor market adjustment processes, the shock axects unemployment in periods subsequent to the shock; and in a dynamically stable system, the unemployment exects will of course die out with the passage of time. We denote the responses of unemployment to the above impulse by $u_{t+j}^{R(T S)}, j, 0$, where $R(T S)$ stands for "response $(R)$ to a temporary shock $(T S)$. This unemployment response is given by the dixerence between the unemployment rate in the presence and absence of the shock. The term $u_{t}^{R(T S)}$ is the immediate impact of the shock, and the whole time series $u_{t+j}^{R(T S)}, j, 0$, is the impulse response function (IRF ) of unemployment. ${ }^{15}$

O ur measure of unemployment persistence, $\pi$, captures the degree to which unemployment is axected by the temporary shock after that shock has disappeared:

$$
\pi={ }_{j=1}^{\mathrm{X}} u_{t+j}^{R(T S)} .
$$

Note that the total exect of the temporary shock is the sum of the immediate response and the persistence measure: $u_{t}^{R(T S)}+\pi$. In the absence of lagged labor market adjustment processes, unemployment would not be axected after the temporary shock has disappeared and thus quantitative unemployment persistence $\pi$ would be zero. At the opposite extreme of hysteresis, the temporary shock would have a permanent exect on unemployment and thus $\pi$ would be in..nite.

\footnotetext{
${ }^{15} \mathrm{G}$ enerally, the IRF is obtained by the in..nite moving average (IMA) representation of the model. Consider, for example, a simple dynamic model for unemployment with one exogenous variable:

$$
u_{t}=\alpha u_{t_{\mathrm{i}} 1}+\beta x_{t}, \mathbf{j} \alpha \mathbf{j}<1 .
$$
}

The IMA representation of $u$ with respect to $x$ is given by

$$
u_{t}=\beta x_{t}+\alpha \beta x_{t_{\mathrm{i}} 1}+\alpha^{2} \beta x_{t_{\mathrm{i}} 2}+\alpha^{3} \beta x_{t_{\mathrm{i}} 3}+\ldots
$$

A ssuming that in period $t$ there is a one-ox unit increase in $x$, the IR $\mathrm{F}$ of the unemployment rate is simply given by the slope coed cients of the above equation:

$$
u_{t}^{R(T S)}=\beta, u_{t+1}^{R(T S)}=\alpha \beta, u_{t+2}^{R(T S)}=\alpha^{2} \beta, u_{t+3}^{R(T S)}=\alpha^{3} \beta, \ldots
$$


We derive persistence measures associated with each of the institutional and price variables ${ }^{16}$ by simulating the empirical model of Section 3. In each simulation, the one ox shock (i.e. the change in an exogenous variable) is introduced in period $t=1$ while all other exogenous variables remain ..xed. In particular, the shock represents a one per cent increase in an exogenous variable that is in logs (e.g. bene.ts), and a one percentage point increase in a variable that is a rate (e.g. interest rate). Note that (a) since our estimated model is dy namically stable, the impulse response functions do not depend on the initial values of the endogenous variables; (b) due to the linearity of the model, the IR F's do not depend on the value at which the other exogenous variables are held constant; and (c) if, instead of a unit shock, we consider a shock of some arbitrary size $(\mathrm{m})$ linearity of the model enables us to compute its impact on unemployment as $u_{t}^{R(T S)} £ m$ (i.e. multiply the size of the shock with the unemployment response to a unit shock).

Table 6 contains two types of persistence measures. P anel A gives the amount of persistence in response to a unit shock in each of the exogenous variables, i.e. the sum of the unemployment responses dełated by the size of each shock. (For example, a one-o. $1 \%$ increase in competitiveness $\left(c_{t}\right)$ reduces unemployment contemporaneously by 0.015 percentage points and, on aggregate, decreases future unemployment by $0.17 \%$.) T his statistic - "normalized persistence" - is useful since it readily enables us to compute the persistence associated with a shock of any size (for each exogenous variable): the actual degree of persistence is simply the product of normalized persistence and the size of the shock.

$P$ anels $B$ and $C$ present estimates of "average persistence" by considering shock sizes that are in line with the historical variation of the exogenous variables. In Panel $B$, for each exogenous variable, the shock size is computed as the standard deviation of the change of the variable for each of the 11 countries in our sample and then taking their arithmetic average. ${ }^{17}$ Then average persistence is calculated as the product of normalized persistence (in Panel A) and the above shock size. Panel C reports "average persistence" when the size of the shock is computed as the average of the absolute value of the change in the series.

\footnotetext{
${ }^{16}$ Except for the tax rate and oil price which, as shown in $\mathrm{F}$ igure 2 , have a negligible impact on the unemployment rate.

${ }^{17}$ A rithmetic averages of course can give only a rough indication of the average variation of the shock. A lter natively, one could weight the shocks of dixerent countries by some measure of their contribution to the EU unemployment rate. For brevity, however, we do not pursue these possibilities here.
} 
O bserve that in all cases competitiveness is associated with the highest degree of unemployment persistence, while bene..ts and interest rates are associated with little persistence.

\begin{tabular}{|c|c|c|c|}
\hline \multicolumn{4}{|c|}{ Table 6: Persistence of temporary shocks (\%) } \\
\hline Panel A & $c_{t}$ & $b_{t}$ & $r_{t}$ \\
\hline size of the shock & 1 & 1 & 1 \\
\hline $\begin{array}{c}\text { "current" exect } \\
u_{t}^{R(T S)}\end{array}$ & -0.015 & -0.003 & 0.000 \\
\hline "future" exect & -0.170 & 0.037 & 0.005 \\
\hline P anel B & $c_{t}$ & $b_{t}$ & $r_{t}$ \\
\hline size of the shock & 6.35 & 4.77 & 1.25 \\
\hline $\begin{array}{l}\text { "current exect } \\
u_{t}^{R(T S)}\end{array}$ & -0.10 & 0.01 & 0.000 \\
\hline "future" exect & -1.08 & 0.17 & 0.006 \\
\hline 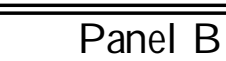 & $c_{t}$ & $\overline{\overline{b_{t}}}$ & $\overline{r_{t}}$ \\
\hline size of the shock & 4.34 & 3.55 & 0.96 \\
\hline $\begin{array}{l}\text { "currente exect } \\
u_{t}^{R(T S)}\end{array}$ & -0.07 & 0.012 & 0.00 \\
\hline "future" exect & -0.74 & 0.13 & 0.005 \\
\hline
\end{tabular}

$\mathrm{F}$ igure 7 plots the impul se response functions of unemployment to these temporary shocks. Since the shock occurs in period $t=1$, the ..gure depicts the changes in unemployment from period 1 onwards (i.e., $\left.u_{1}^{R(T S)}, u_{2}^{R(T S)}, u_{3}^{R(T S)}, \ldots.\right) .^{18}$

Figure 7. Unemployment Effects of Temporary Shocks
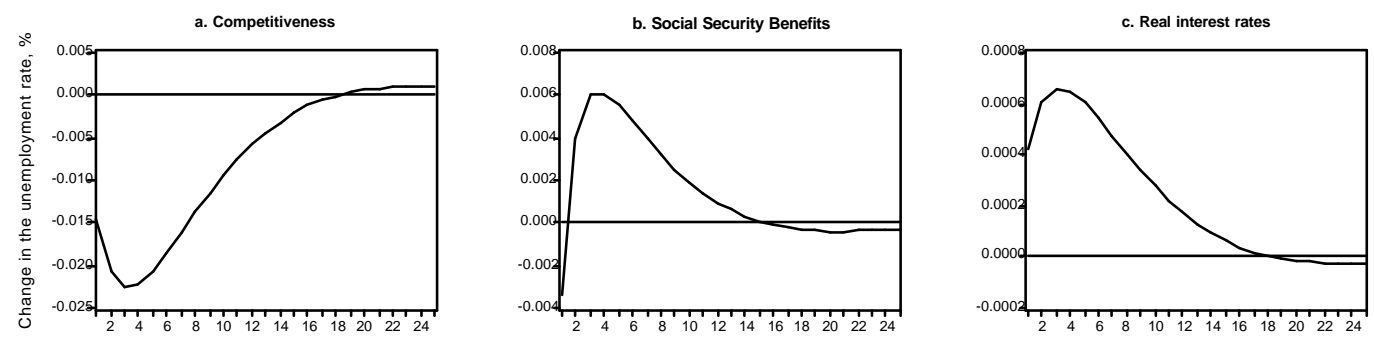

The shock is a one-off $1 \%$ increase in the exogenous variable in period $\mathrm{t}=1$.

\footnotetext{
${ }^{18}$ Since the size of the shock does not axect the time path of the responses but only rescales them, the plots in Figure 7 have been generated by a unit size shock.
} 
Next we examine the unemployment exects of a unit permanent shock $(P S)$ that starts in period $t$. O ur measure of imperfect responsiveness, $\rho$, captures the degree to which unemployment does not adjust fully to the new long-run equilibrium. In particular, it is speci..ed as the sum of the dixerences through time between (a) the disparity between actual and long-run unemployment in the presence of the shock and (b) this disparity in the absence of the shock. This is equival ent to the dixerences through time between (a) the disparity 3 between the actual unemployment rate in the presence and absence of the shock $u_{t+j}^{R(P S)}$, where $R(P S)$ stands for the "response $(R)$ to a permanent shock $(P S)$, and (b) the disparity between'the long-run unemployment rate in the presence and absence of the shock $u_{L R}^{R(P S)}::^{19}$

$$
\rho={ }_{j=0}^{\mathbf{X}^{1}} u_{t+j}^{R(P S)} \text { i } u_{L R}^{R(P S)}
$$

In the absence of lagged labour market adjustment processes, unemployment would be "perfectly responsive," i.e. $\rho$ would be zero. If however the full effects of the permanent labour demand shock emerge only gradually, so that the short-run unempl oyment exects of the shock are less than the long-run exect, then unemployment will be "under-responsive:" $\rho<0$, i.e. unemployment displays inertia. However if unemployment overshoots its long-run equilibrium, then our measure may be positive, making unemployment "over-responsive:" $\rho>0$. Under hysteresis, $\rho$ is in...nite

\footnotetext{
${ }^{19}$ The disparity betwen the long-run unemployment rate in the presence and absence of the shock is de..ned as

$$
u_{L R}^{R(P S)}, \lim _{j ! 1} u_{t+j}^{R(P S)} .
$$

M oreover, each permanent shocks may be viewed as an in..nite sequence of temporary shocks. Thus, the unemployment response in period $t+j, j, 0$, to the unit permanent shock may be expressed by the sum of all unemployment responses to the corresponding temporary shocks up to that period:

$$
u_{t+j}^{R(P S)}={ }_{i=0}^{X^{j}} u_{t+i}^{R(T S)} .
$$
}

Thus the long-run response to the permanent shock is

$$
u_{L R}^{R(P S)}={ }_{i=0}^{\text {入 }} u_{t+i}^{R(T S)}=u_{t}^{R(T S)}+\pi .
$$


The permanent shocks in our model are associated with the growth drivers, viz., the capital stock $\left(k_{t}\right)$ and working age population $\left(z_{t}\right)$. A ssuming that these variables are generated by a random walk with drift, welet the permanent shock be represented by a one-ox change in their period $t$ growth rates. P anel A in Table 7 gives the change in the long-run unemployment rate and our measure of imperfect responsiveness for a percentage point decrease (increase) in the growth rate of capital stock (working-age population). For example, a 1\% permanent decrease in capital stock leads to a $0.17 \%$ increase in the long-run unemployment rate and produces unemployment over-responsiveness of $2.9 \%$. We call this statistic "normalized responsiveness". In our model, the unemployment responds to a permanent shock in both capital stock and population by overshooting, as shown in Figure 8.

\begin{tabular}{|c|c|c|}
\hline Panel A & $\begin{array}{c}\text { permanent decrease in } \\
k_{t}\end{array}$ & permanent increase in \\
\hline $\begin{array}{l}\text { size of the shock } \\
m\end{array}$ & -1 & 1 \\
\hline resp onsiveness & 2.9 & 4.56 \\
\hline $\begin{array}{c}\text { Tong-run exect } \\
u_{L R}^{R(P S)}\end{array}$ & 0.17 & 0.42 \\
\hline Panel B & $\begin{array}{c}\text { permanent decrease in } \\
k_{t}\end{array}$ & $\begin{array}{c}\text { permanent increase in } \\
z_{t}\end{array}$ \\
\hline $\begin{array}{l}\text { size of the shock } \\
m\end{array}$ & -1.30 & 0.68 \\
\hline resp onsiveness & 3.77 & 3.10 \\
\hline$u_{I R}^{R(P S)}$ & 0.22 & 0.29 \\
\hline Panel C & $\begin{array}{c}\text { permanent decrease in } \\
k_{t}\end{array}$ & $\begin{array}{c}\text { permanent increase in } \\
z_{t}\end{array}$ \\
\hline $\begin{array}{l}\text { size of the shock } \\
m\end{array}$ & -3.39 & 0.61 \\
\hline $\begin{array}{c}\text { resp onsiveness } \\
\rho \\
\text { long-run exect }\end{array}$ & 9.83 & 2.78 \\
\hline$u_{L R}^{R(P S)}$ & 0.58 & 0.26 \\
\hline
\end{tabular}

Similarly to our persistence measures, dixerent sizes of the permanent shock lead to a rescaling of the normalized measures given in Panels $B$ and $C$ of Table 7. One plausible measure of the size of the permanent shock of a growth driver series is obtained by the standard deviation of the change of the series: 1.30 for 
capital stock and 0.68 for population. ${ }^{20}$ Then "average responsiveness" (in Panel $B$ of Table 7) may be computed as the product of normalized responsiveness and the size of the shock. When capital stock is permanently reduced by $1.3 \%$, unemployment overshoots by 3.77 percentage points before it stabilizes to its new long-run value of $0.22 \%$. On the other hand, a $0.68 \%$ increase in population generates $3.1 \%$ of unemployment overshooting until unemployment stabilizes at $0.29 \%$.

A $n$ alternative way to measure the size of the shock is by considering the average change (in absolute terms) in the growth driver series: 3.39 for capital stock and 0.61 for population. ${ }^{21}$ Panel C of Table 7 shows that a $3.39 \%(0.61 \%)$ permanent decrease (increase) in capital stock (population) yields 9.83 (2.78) percentage points of unemployment overshooting through time. Note that theaverage responsiveness measures indicate that capital stock is more over-responsive than population (Panels B-C, Table 7). However, when we normalize by the size of the shock capital stock is less over-responsive than population ( $P$ anel A, Table 7).

\footnotetext{
${ }^{20}$ Since we assume that (the log of) capital stock is generated by the stochastic process: $k_{t}=g+k_{t_{\mathrm{i}} 1}+\varepsilon_{t}$, the growth rate of capital stck is given by $\pitchfork k_{t}=g+\varepsilon_{t}$, where $\varepsilon_{t} \gg N^{1} 0, \sigma_{k}^{2}$. Thus a on e-o shock to the growth rate $\left(\$ k_{t}\right)$ gives rise to a permanent change in capital stock. We measure the size of the shock as the standard deviation of the growth rate series, $\sigma_{k}$. (Of course, the size of the shock reported in Table 7 is the arithmetic mean of the standard deviations of the individual countries in our sample.) Under the assumption of normality, this means that there is a $35 \%$ chance that the magnitude of the unexpected decrease or increase in the capital stock growth rate is between 0 and $\sigma_{k}$. (Similarly, for population.)

${ }^{21}$ In particular, we measure the size of the shock in the capital stock as $\frac{1}{N} \mathrm{P}_{i=1} \frac{1}{T} \mathrm{P}_{T}{ }_{t=1} \mathrm{j}$ \& $k_{i t} \mathrm{j}$, where $N$ and $T$ are the number of countries and years in our sample. (Similarly, for the population shock.)
} 
Figure 8: Effects of Permanent Shocks

a. Working-age population

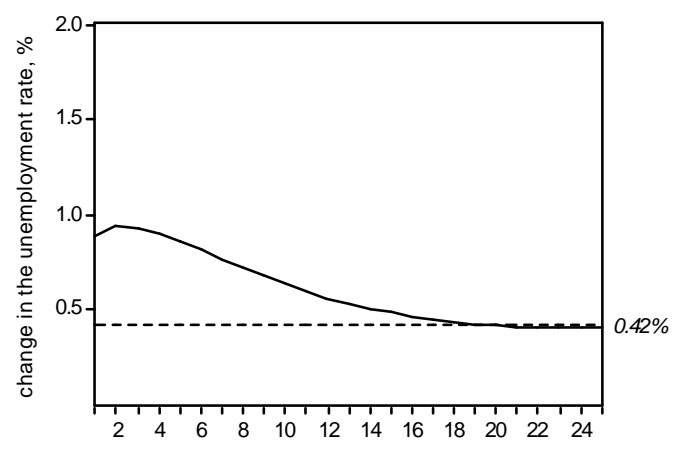

b. Capital stock

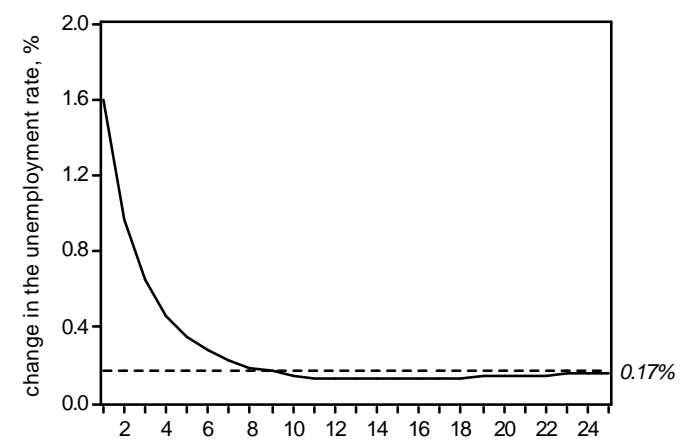

The shock is a

$1 \%$ permanent increase in working age population

$1 \%$ permanent decrease in capital stock.

\section{Conclusions}

This paper takes a fresh look at the sources of unemployment in the E uropean $U$ nion. The analysis focuses on prolonged adjustments to labor market shocks, in the form of changes in institutional variables, price variables, and growth drivers (the capital stock and working-age population). We derive the unemployment responses to these shocks and compute the dynamic contributions of each shock to the movements in unemployment. In this context, it emerges that the growth drivers play a particularly important role in accounting for the main swings in EU unemployment. Regarding the institutional variables, social security bene..ts play a more important role than taxes; and regarding the price variables, competitiveness plays a more important role than interest rates and oil prices.

We argue that our results dixer from those in the mainstream literature since we focus on prolonged labor market adjustments in the context of a dynamic multi-equation system. We have shown that single-equation models understate the importance of lagged adjustments. 


\section{R eferences}

[1] Baltagi, B . H. (1995): Econometric Analysis of P anel Data, New Y ork: Wiley.

[2] Baltagi, B. H. and J . M. Grił n (1997): "Pooled estimators vs. their heterogeneous counterparts in the context of dynamic demand for gasoline", J ournal of E conometrics, No. 77, 303-327.

[3] Baltagi, B. H. and K ao (2000): “N onstationary Panels, Cointegration in Panels and Dynamic Panels: A Survey", mimeo.

[4] Banerjee A. (1999): "Panel Data Unit Roots and Cointegration: An Overview", Oxford Bulletin of Economics and Statistics, special issue, 607629.

[5] Blanchard, O.J . and J. Wolfers (2000): "The R ole of Shocks and Institutions in the R ise of European Unem pl oyment: The A ggregate Evidence", Economic J ournal, 110, M arch.

[6] Daveri, F. and G. Tabellini (2000): Unemployment, G rowth and Taxation in Industrial Countries", Economic Policy, 0 (30), 47-88.

[7] Fisher, R. A . (1932): Statistical Methods for Research Workers, Edinbutgh: Oliver \& Boyd.

[8] Henry, S.G.B. and D.J . Snower ( 1996), E conomic Policies and U nemployment Dynamics in Europe, International Monetary Fund Publications.

[9] Henry, S.G.B., M. Karanassou, and D.J. Snower (2000), "Adjustment Dynamics and the Natural R ate", Oxford Economic Papers, 52, 178-203.

[10] Hsiao, C. (1986): Analysis of Panel Data, Cambridge: Cambridge University Press.

[11] Karanassou, M., and D.J . Snower (1998), "How Labor M arket Flexibility A xects Unemployment: Long-Term Implications of the Chain R eaction Theory", The E conomic J ournal, 108, May, 832-849.

[12] K aranassou, M. and D.J . Snower (2000). "Characteristics of Unemployment Dynamics: The Chain R eaction A pproach", IZA Discussion Paper, 127, IZA, Bonn. 
[13] Karanassou, M., H. Sala, and D.J. Snower (2003): "Unemployment in the European Union: A Dynamic Reappraisal", Economic Modelling, 20, 237273.

[14] Layard, P.R.J ., S.J . Nickell and R . J ackman (1991): Unemployment: Macroeconomic Performance and the Labor Market, Oxford: Oxford University Press.

[15] Maddala, G. S. and S. Wu (1999): "A comparative Study of Unit Root Tests with Panel Data and a New Simple Test", Oxford Bulletin of Economics and Statistics, special issue, 631-652.

[16] Phelps, E. S. ( 1994): Structural B ooms: The Modern Equilibrium Theory of Unemployment, Interest and Assets, Harvard University Press, Cambridge (MA).

[17] Phelps, E. and G. Zoega (1998): "Natural Rate Theory and E urope's Unemployment", The Economic J ournal, 108, pp. 782-801.

[18] Phelps, E. and G. Zoega (2001): "Structural booms: productivity expectations and asset valuations," E conomic Policy, 32, A pril, 85-126.

[19] Smith, R. P. (2000): “E stimation and inference with non-stationary panel time-series data", mimeo. 


\section{IZA Discussion Papers}

\begin{tabular}{|c|c|c|c|c|}
\hline No. & Author(s) & Title & Area & Date \\
\hline 885 & $\begin{array}{l}\text { A. Constant } \\
\text { K. F. Zimmermann }\end{array}$ & $\begin{array}{l}\text { The Dynamics of Repeat Migration: A Markov } \\
\text { Chain Analysis }\end{array}$ & 1 & $10 / 03$ \\
\hline 886 & $\begin{array}{l}\text { J. J. Dolado } \\
\text { M. Jansen } \\
\text { J. F. Jimeno }\end{array}$ & $\begin{array}{l}\text { On-the-Job Search in a Matching Model with } \\
\text { Heterogenous Jobs and Workers }\end{array}$ & 1 & $10 / 03$ \\
\hline 887 & $\begin{array}{l}\text { B. Irlenbusch } \\
\text { D. Sliwka }\end{array}$ & $\begin{array}{l}\text { Transparency and Reciprocal Behavior in } \\
\text { Employment Relations }\end{array}$ & 7 & $10 / 03$ \\
\hline 888 & W. Koeniger & $\begin{array}{l}\text { Collective Dismissal Cost, Product Market } \\
\text { Competition and Innovation }\end{array}$ & 3 & $10 / 03$ \\
\hline 889 & D. E. Wildasin & $\begin{array}{l}\text { Fiscal Policy, Human Capital, and Canada-US } \\
\text { Labor Market Integration }\end{array}$ & 2 & $10 / 03$ \\
\hline 890 & $\begin{array}{l}\text { M. Bratti } \\
\text { L. Mancini }\end{array}$ & $\begin{array}{l}\text { Differences in Early Occupational Earnings of } \\
\text { UK Male Graduates by Degree Subject: } \\
\text { Evidence from the 1980-1993 USR }\end{array}$ & 6 & $10 / 03$ \\
\hline 891 & $\begin{array}{l}\text { L. Flood } \\
\text { E. Pylkkänen } \\
\text { R. Wahlberg }\end{array}$ & $\begin{array}{l}\text { From Welfare to Work: Evaluating a Proposed } \\
\text { Tax and Benefit Reform Targeted at Single } \\
\text { Mothers in Sweden }\end{array}$ & 6 & $10 / 03$ \\
\hline 892 & B. T. Hirsch & What Do Unions Do for Economic Performance? & 5 & $10 / 03$ \\
\hline 893 & K. Sabirianova Peter & $\begin{array}{l}\text { Skill-Biased Transition: The Role of Markets, } \\
\text { Institutions, and Technological Change }\end{array}$ & 4 & $10 / 03$ \\
\hline 894 & R. Winkelmann & Parental Separation and Well-Being of Youths & 7 & $10 / 03$ \\
\hline 895 & $\begin{array}{l}\text { J. M. Fitzgerald } \\
\text { D. C. Ribar }\end{array}$ & $\begin{array}{l}\text { Transitions in Welfare Participation and Female } \\
\text { Headship }\end{array}$ & 3 & $10 / 03$ \\
\hline 896 & S. W. Polachek & $\begin{array}{l}\text { What Can We Learn About the Decline in U.S. } \\
\text { Union Membership from International Data? }\end{array}$ & 2 & $10 / 03$ \\
\hline 897 & $\begin{array}{l}\text { M. Brown } \\
\text { A. Falk } \\
\text { E. Fehr }\end{array}$ & $\begin{array}{l}\text { Relational Contracts and the Nature of Market } \\
\text { Interactions }\end{array}$ & 7 & $10 / 03$ \\
\hline 898 & $\begin{array}{l}\text { G. J. van den Berg } \\
\text { A. G. C. van Lomwel } \\
\text { J. C. van Ours }\end{array}$ & $\begin{array}{l}\text { Nonparametric Estimation of a Dependent } \\
\text { Competing Risks Model for Unemployment } \\
\text { Durations }\end{array}$ & 1 & $10 / 03$ \\
\hline 899 & $\begin{array}{l}\text { M. Karanassou } \\
\text { H. Sala } \\
\text { D. J. Snower }\end{array}$ & $\begin{array}{l}\text { Unemployment in the European Union: } \\
\text { Institutions, Prices, and Growth }\end{array}$ & 2 & $10 / 03$ \\
\hline
\end{tabular}

An updated list of IZA Discussion Papers is available on the center's homepage www.iza.org. 